\title{
Concept Maps as a Tool for Teaching Organic Chemical Reactions
}

\author{
Barbara Šket, ${ }^{*, 1}$ Saša Aleksij Glažar ${ }^{2}$ and Janez Vogrinc ${ }^{3}$ \\ ${ }^{1}$ OŠ Log-Dragomer \\ ${ }^{2}$ University of Ljubljana, Faculty of Education \\ * Corresponding author: E-mail: (barbara.sket@guest.arnes.si)
}

Received: 19-10-2014

\begin{abstract}
\section{Abstract}

The purpose of the research was to establish the impact of the application of a concept map in chemistry lessons on the effective solving of tasks with organic reactions content. In the first phase of the research, a concept map was produced representing the reactions of hydrocarbons, organic halogenated compounds and organic oxygen compounds, and in the second phase the produced concept map was introduced in lessons. Its impact was tested on a sample consisting of 186 students (average age of 17.8 years), who were divided into a control group (88 students) and an experimental group (98 students). Prior to the experiment, the two groups were equalized in terms of their level of development of formal logical thinking and their average grade in chemistry. A knowledge test, consisting of five problem tasks comprising multiple parts, was used as a quantitative instrument for measuring the impact of the applied concept map. The content of the knowledge test was selected on the basis of the chemistry lesson plan (reactions of organic oxygen compounds) for general upper secondary schools (in Slovenian: gimnazija). An analysis of the task solving showed statistically significant differences in the responses of the experimental group members and the control group members (experimental group $\mathrm{M}$ $=15.9 ; \mathrm{SD}=6.33$; control group $\mathrm{M}=13.6 ; \mathrm{SD}=7.93 ; \mathrm{p}=0.03$ ). The produced concept map contributed to the more effective interrelation of concepts and, consequently, to more effective problem task solving.
\end{abstract}

Keywords: concept maps, meaningful learning, organic oxygen compounds

\section{Introduction}

The recent trends in the development of chemistry education in Slovenia have been considered in numerous articles addressing the areas of (1) studying the impact of the introduction of modern experimental methods in chemistry on school practice, e.g. the impact of the visible spectrometry concepts through hands-on laboratory work on students' learning in the scope of four vocational programmes, ${ }^{1}$ (2) studying the impact of the online knowledge assessment system on students' knowledge, ${ }^{2}$ (3) establishing the importance of practical pedagogical training in primary schools for teacher education, ${ }^{3}$ and (4) the development of concept maps as learning materials to foster students' meaningful learning of organic reactions. ${ }^{4}$ The results of the introduction of concept maps as a tool for teaching organic chemical reactions in high schools are presented in this paper.
The starting point of the development of concept maps is the assimilation theory of learning proposed by Ausubel $^{5}$ in contrast to conventional rote learning. It is based on Piaget's genetic epistemology and focuses on the assimilation hypothesis, which assumes that new learning experiences are integrated into the learner's pre-existing knowledge structure. ${ }^{6}$ Referring to the assimilation theory of cognitive learning, Novak and Gowin ${ }^{7}$ proposed the concept map as a tool for teaching, learning and evaluation. Concept mapping was originally developed by Joseph D. Novak in the $1972,{ }^{8}$ based on the meaningful learning theory of Ausubel. ${ }^{9}$ Concept maps are visual/spatial representations of ideas and concepts, as well as of their interrelationships. The configurations of concept maps are determined by the logical structure of the abstract concepts. They contain symbolic representations of aspects of a complex concept, the relations between the components of the concept, and the links between theory and applica- 
tions. ${ }^{10}$ In concept maps, the cognitive structure of conceptual knowledge is hypothetically represented by a hierarchical network. ${ }^{11}$ Concept maps include concepts and relationships between concepts, indicated by a connecting line and a linking word, which specify the relationship between the two concepts. ${ }^{12}$ Another feature of a concept map is the ability to search for and characterize crosslinks. Cross-links are relationships (linking lines with linking words) between concepts in different domains of the concept map. The concept arrangement and the linking line orientation determine the map's structure. Concept maps have a vertical and horizontal hierarchical structure. The vertical hierarchy is reflected downward from general to more specific concepts, whereas in the horizontal hierarchy the related concepts are structured along the same horizontal line; such a hierarchical structure can be represented by the ordered-tree technique. There are also socalled circular concept maps, which consist of concentric circles, expanding from the general concept in the centre.

Concept maps are "tools intended for organizing what the learner knows" and for "engaging learners in relating new ideas to what they already know". ${ }^{13}$ Concept mapping techniques are interpreted as structures representative of students' knowledge. ${ }^{7,14}$ Concept maps visualize the relationships between the key concepts in a semantic way ${ }^{16}$ and aid the development of meaningful teaching, which supports critical thinking rather than a surface approach. ${ }^{17}$ They can be used as an advanced organizer to improve learner achievement and to allow students to reflect on their own misunderstanding..$^{18,19,20}$ Concept maps have been widely employed to help students organize their knowledge as well as to evaluate their knowledge structures in a wide range of subject matters. ${ }^{21}$ The concept mapping perception contributes to knowledge transfer in five learning stages: acquisition, communication, application, acceptance, and assimilation. ${ }^{22}$ The research results supported the use of concept maps in: (1) promoting meaningful learning; (2) providing for an additional learning resource; (3) conducting learning assessment; and (4) establishing the knowledge development. ${ }^{23,24}$

Concept mapping was also introduced to developing and revising the curriculum. In the process of constructing such maps educators can better identify the curriculum redundancy, omission, complexity, misconceptions and the required concept assessment. ${ }^{24}$ In many science textbooks, the inclusion of concept mapping is a way of summarizing the students' understanding after they have studied a chapter. When concept maps are used in instruction, they can also serve the purposes of evaluation. ${ }^{12}$ Teaching a new chapter may begin with a concept map that includes the concepts and links central to the content of the chapter. While working, a particular part of the map is then gradually addressed. Such concept maps are made up of separate modules, representing separate subheadings. When the entire chapter has been dealt with, a synthesis of the concepts discussed in the chapter is provided by the entire map.
Concept maps can also provide a graphical view of how students organize, connect and synthesise information. Concept maps allow students to think about concepts related to specific topics by helping them to better understand and organize what they have learned, and to store and retrieve information more efficiently. ${ }^{25}$ The creation of concept maps by students is an open-ended activity that allows for: (1) reflection on differences in the students' knowledge structures, (2) identification of the students' partial understanding and misconceptions, (3) creating opportunities for the students to determine their conceptual understanding, and (4) the development of high-order cognitive processes, such as explaining and planning. ${ }^{15}$

Research studies related to concept mapping indicate that concept mapping has positive effects both on students' achievement as well as on their attitude. A study by BouJaoude and Attieh ${ }^{27}$ sought to examine the effect of using concept maps as a study tool on achievement in chemistry. The results showed that females achieved higher scores in chemistry tests than males. The research findings of Quis ${ }^{28}$ revealed statistically significant differences between the scores of an experimental group and a control group in relation to the use of concept maps. Can$\operatorname{dan}^{29}$ studied the effect of concept mapping on primary school students' understanding of the concept of force and motion. The results showed that there was a significant difference between the achievements of an experimental group and a control group.

In a research study by Erdem, Yimaz and Oskay ${ }^{30}$ the effect of hypermedia-hypertext and paper-pencil type concept maps on students' meaningful learning in the subject of atom and bonding was examined. An atom-bonding test and concept maps were used as data collection tools. It was established that concept maps created using the hypermedia-hypertext technique contribute to the students' meaningful learning.

According to a study by Qarareh, ${ }^{17}$ concept mapping can also be a powerful method to organize complex problems, and can help students to understand and integrate concepts, as well as enhancing their interest in learning. Students exposed to concept maps throughout their general chemistry course make more connections between concepts than students who are not exposed to concept maps. ${ }^{31}$

In the application of concept maps, the pre-knowledge of the concepts included in the map is important. This is confirmed by research conducted by Gurlitt and Renken ${ }^{32}$ which showed that the use of concept maps triggered the necessary pre-knowledge. The linking of concepts in maps facilitated learning with understanding, and, consequently, the synthesis of knowledge, which also affected the attitude of students to chemistry.

\section{1. The Purpose}

The aim of the present study is to determine the effect of a concept map prepared by experts on the sub- 


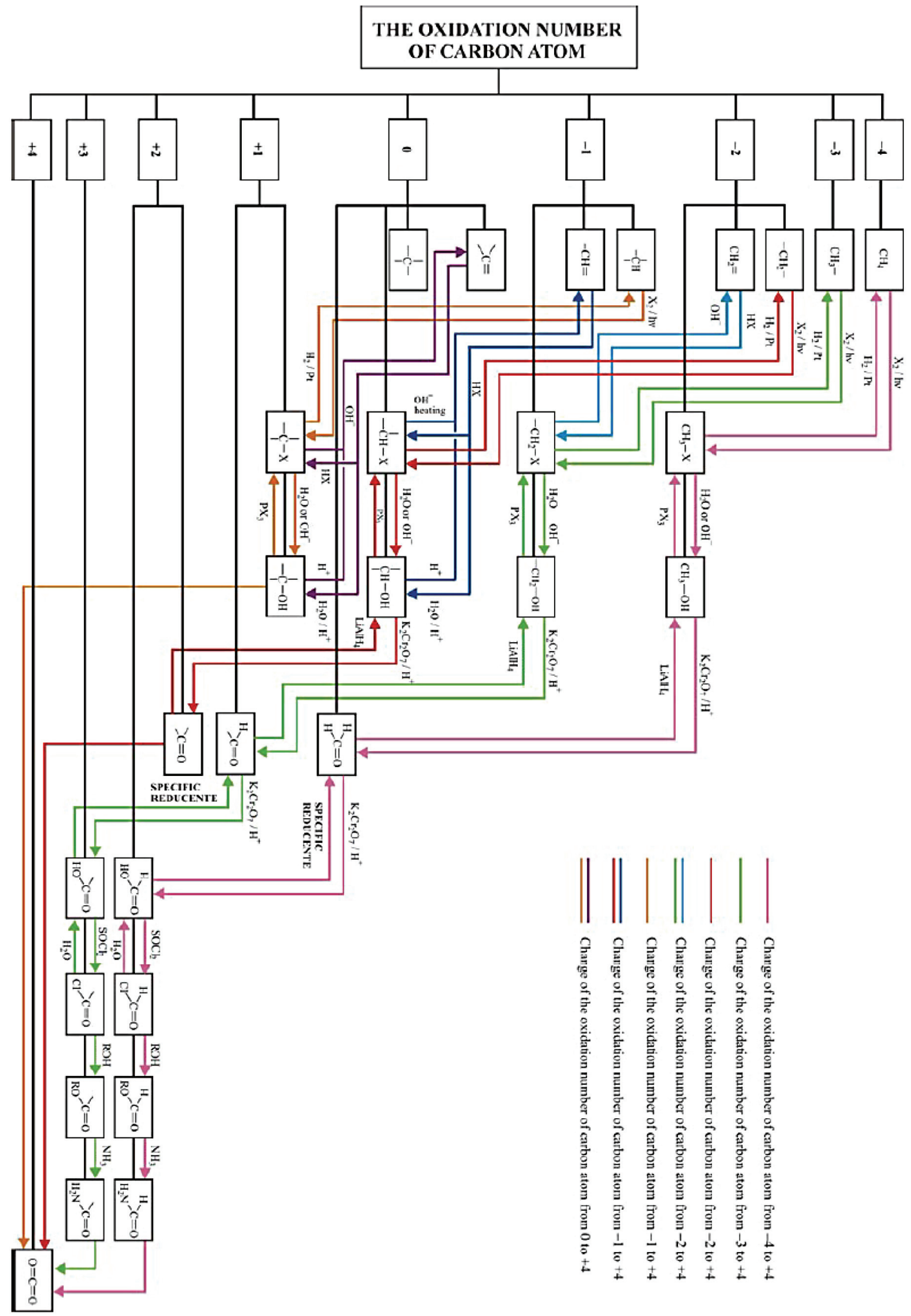

Scheme 1. Concept map for the reactions of hydrocarbons, organic halogenic compounds and organic oxygen compounds 
ject of organic chemical reactions on students' meaningful learning, and to establish whether using the concept map method in teaching has any effect on the effective solving of tasks with organic reactions content.

\section{Method}

\section{1. Participants}

The study sample comprised 186 students of general upper secondary school (in Slovenian: gimnazija). There were 54 male students and 132 female students, with an average age of 17.8 years. The students were divided into a control group ( 24 male, 64 female students, together 88 students) and an experimental group (30 male, 68 female students, together 98 students).

\section{2. Instruments}

\section{2. 1. Concept Map}

The elaborated concept map includes reactions for three types of organic molecules: hydrocarbons, organic halides and organic oxygen-containing compounds. ${ }^{23}$ The basis for the production of the concept map is the oxidation number of the carbon atom, which is determined with regard to the electronic affinity of the carbon atom as compared to the hydrogen atom or a hetero atom. This number is determined so that for each bond between a carbon atom and hydrogen atom a value of -1 is used, for each bond with another carbon atom the value is 0 , and for each bond with a hetero atom (halogen, oxygen, nitrogen, sulfur) the value is +1 . Thus, a carbon atom can have an oxidation number ranging from -4 (as in the case of methane) to +4 (as in the case of the carbon dioxide). Changes connected with the changing of oxidation numbers from -4 to +4 represent oxidations, whereas changes in the opposite directions stand for reductions (Scheme 1).

\section{2. 2. The Organic Reactions Knowledge Test}

In order to measure the impact of the applied concept map on the students' knowledge of organic reactions, a knowledge test was constructed on the basis of the chemistry lesson plan for general upper secondary schools.

The knowledge test consisted of five problem tasks, each comprising several sub-questions. The problem solving was associated with the use of the concept map. The questions were prepared by the researchers and their validity was established by chemistry education experts. In the research, the solving of three out of five tasks was analysed. It took the students 45 minutes to complete the knowledge test.

\section{2. 3. Test of Logical Thinking ${ }^{33}$}

Tobin and Capie's Test of Logical Thinking (TOLT) provides multiple justifications, as well as multiple solutions for each reasoning mode tested. The test consists of two questions for each of the five reasoning modes for a total of 10 items. The rationale behind the TOLT follows: (1) proportional reasoning; (2) controlling variables; (3) probabilistic reasoning; (4) correlation reasoning; (5) combinatorial reasoning.

\section{2. 4. Data Analysis}

The present study takes into account the following variables:

- Independent variables: teaching method (concept mapping and traditional); gender.

- Dependent variable: students' achievement.

- The Statistical Package of Social Sciences (SPSS) was used for data analysis.

In the empirical research, we employed the causalexperimental method of educational research. The data from tests were processed using methods of descriptive and inferential statistics. The statistical procedures employed were: the frequency distribution (f, $\mathrm{f} \%$ ) of the attributive variables, basic descriptive statistics of the numerical variables (mean, standard deviation), the Chi-square test for independence ( $\chi^{2}$-test of hypothesis independence), the t-test for independent samples and the Pearson correlation coefficient. Chi-square test for independence was used to evaluate the relationship between two variables measured on nominal or ordinal scales (first variable: experimental or control group; second variable: answers on a task: correct, incorrect, no answer). T-test for independent samples was used to determine if the means of two unrelated samples differ. ${ }^{34}$

\section{3. Research Design}

In the first phase of the research, a concept map representing the reactions of hydrocarbons, halogenated hydrocarbons and oxygen containing hydrocarbons was produced by experts, ${ }^{4}$ and in the second phase the produced concept map was introduced into teaching and solving problems of organic reactions. The students learned about sets of chemical reactions in which the oxidation number of carbon changed, ranging from -4 to +4 , from -3 to +4 , from -2 to +4 , from -1 to +4 , and from 0 to +4 . With a concept map, it is possible to interlink individual reactions and show the stages along the path from reactants to products. The experiment was conducted over two months. At the end of lessons the students in the control group (subjected to classical teaching) and in the experimental group (subjected to teaching using the concept map) took the same knowledge test. At the knowledge test the students of the experimental group did not use the concept map. 


\section{Results}

Before the experiment, the control group and the experimental group were equalized using the Test of Logical Thinking (Tobin and Capie, 1981) and according to the students' average grades in chemistry. Tobin and Capie's Test of Logical Thinking (TOLT) provides multiple justifications, as well as multiple solutions for each reasoning mode tested. The test consists of two questions for each of the five reasoning modes for a total of 10 items. The rationale behind the TOLT follows: (1) proportional reasoning; (2) controlling variables; (3) probabilistic reasoning; (4) correlation reasoning; (5) combinatorial reasoning.

Students who cannot reason proportionally have difficulty understanding equations and functional relationships.

There was no statistically significant difference in the level of development of logical thinking between the two groups, nor was there a statistically significant difference $(t(175)=-1.4 ; p=0.163)$ between the average final grade in chemistry between the students in the experimental group $(\mathrm{M}=3.7 ; \mathrm{SD}=0.89)$ and the control group $(\mathrm{M}=$ 3.6; $\mathrm{SD}=0.99$ ). As there are no significant differences between the two groups, it is assumed that the two groups are equivalent.

The knowledge test achievements show a statistically significant difference at the level of significance $\mathrm{p}=$ 0.03 between the experimental group $(\mathrm{M}=15.9$; $\mathrm{SD}=$
$6.33 ; \mathrm{t}(148)=-2.19)$ and the control group $(\mathrm{M}=13.6 ; \mathrm{SD}$ $=7.93 ; \mathrm{t}(166.35)=-2.16)$. Pearson's correlation coefficient shows that there is a moderately strong correlation between the chemistry grades and the knowledge test achievements $(\mathrm{r}=0.321 ; \mathrm{p} \leq 0.000)$.

The achievements of the students in the experimental group, who were taught with a concept map, were higher than those of the students in the control group, taught with a traditional method.

\section{1. Examples of Concept Map Application in Organic Compounds Reactions}

As an example, a set of four interrelated tasks is presented. The first task addresses the reaction of halogenation of alkanes (butane with chlorine), while the second and third tasks are based on the products of the first reaction (1-chloropropane and 2-chloropropane). The former addresses the elimination of hydrogen halide, whereas the latter deals with the substitution of the halogen atom with a hydroxyl group.

The reactants in the second and the third reactions are the same, but the conditions under which the reactions take place are different. The elimination of hydrogen halide is carried out with ethanolic potassium hydroxide solution under heating, whereas the substitution of a halogen atom with a hydroxyl group is triggered with an aqueous solution of sodium hydroxide.

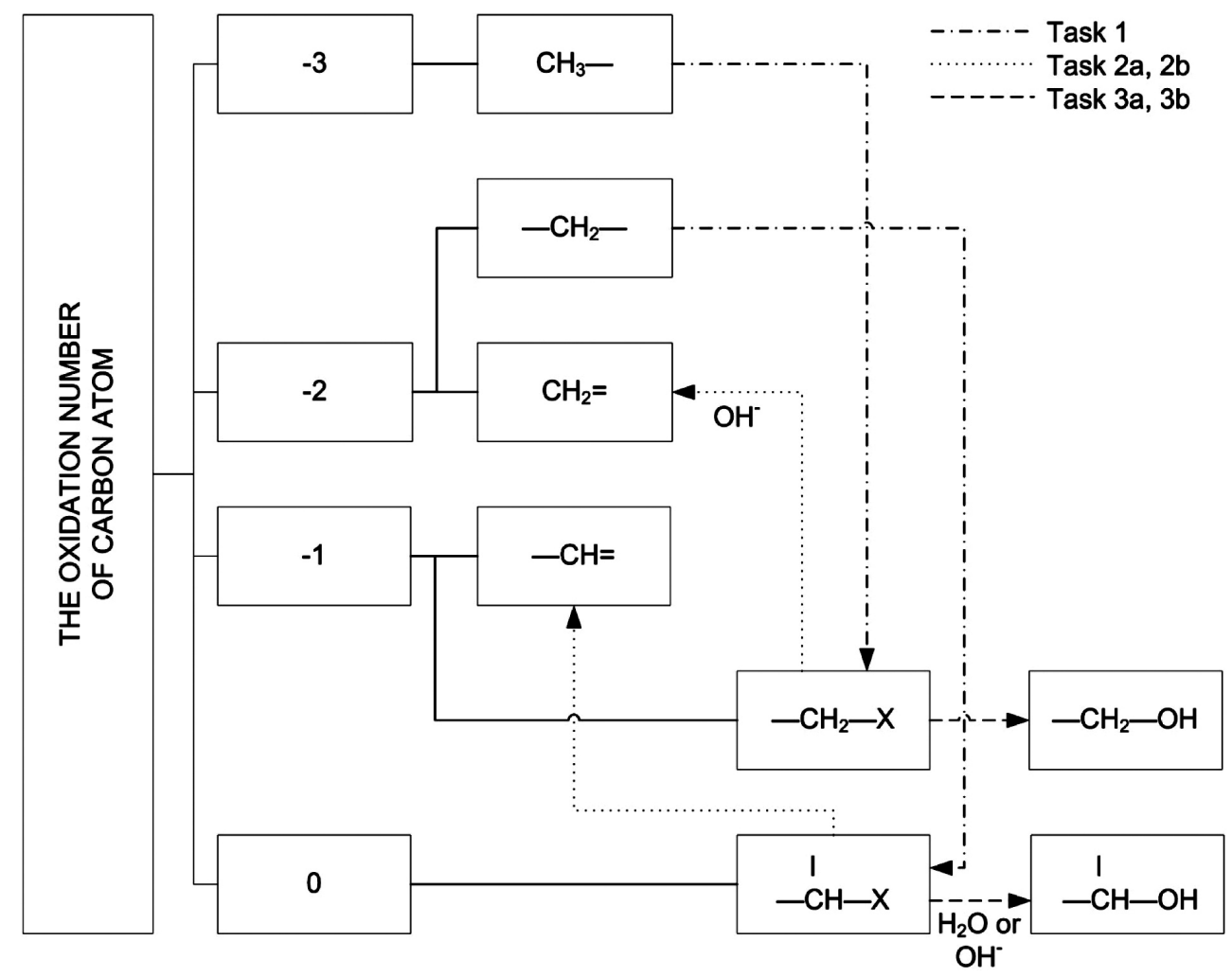

Scheme 2. A part of the concept map is given, dealing with the reactions in Tasks 1, 2 and 3. 
Task No. 1

The oxidation number of the carbon changes from -3 to -1 in the halogenation of the primary carbon, whereas in the halogenation of the secondary carbon it changes from -2 to 0 .

Task No. 2

The oxidation number of the carbon changes from -1 to -2 in the elimination of hydrogen halide from 1-halogenoalkane, whereas it changes from 0 to -1 in the elimination of hydrogen halide from 2-halogenoalkane.

Task No. 3

The oxidation number of the carbon does not change in the substitution of the halogen atom with a hydroxyl group in the 1-halogenoalkane and in the 2-halogenoalkane.

\section{1. 1. Task No. 1}

Write down the reaction scheme for the reaction of butane with chlorine in the presence of light.

$$
\text { butane }+ \text { chlorine } \rightarrow \text { mono-substituted products }+\mathrm{y}
$$

\section{Solution}

In the reaction, two mono-substituted products, i.e., 1-chlorobutane and 2-chlorobutane, are formed, which is also evident from the concept map.
There is a statistically significant difference $\left(\chi^{2}=\right.$ $8.727 ; \mathrm{df}=2 ; 2 \mathrm{P}=0.013$ ) between the answers of the students who used the concept map as a teaching and learning technique and those who did not use the concept map.

The students wrote down the corresponding molecular formula $\mathrm{C}_{4} \mathrm{H}_{9} \mathrm{Cl}$, which did not show that the reaction of radical chlorination of butane leads to the formation of a mixture of two mono-substituted products, i.e., 1-chlorobutane and 2-chlorobutane, $(9.2 \% \mathrm{EG}, 12.5 \% \mathrm{CG})$. A common mistake was to record the molecular formula of the di-substituted product $\mathrm{C}_{4} \mathrm{H}_{8} \mathrm{Cl}_{2}(5.1 \% \mathrm{EG}, 3.4 \% \mathrm{CG})$. The students who made this mistake had not read the instructions carefully, as this task requires the recording of mono-substituted products and not di-substituted products. In addition, in the reaction equation the students incorrectly stated that hydrogen was formed.

From the smaller proportion of students who also correctly noted the second product of chlorination (2chlorobutane), it can be concluded that these students took into account the fact that the butane molecule comprises both the methyl group as well as the methylene group.

\section{1. 2. Task No. 2}

Draw the products formed when the mixture of 1chloropropane and 2-chloropropane is heated in an ethanolic solution of potassium hydroxide $(\mathrm{KOH} / \mathrm{EtOH})$.

$$
\mathrm{CH}_{3} \mathrm{CH}_{2} \mathrm{CH}_{2} \mathrm{CH}_{3}+\mathrm{Cl}_{2} \rightarrow \mathrm{CH}_{3} \mathrm{CH}_{2} \mathrm{CH}_{2} \mathrm{CH}_{2} \mathrm{Cl}+\underset{\mathrm{Cl}}{\mathrm{CH}_{3} \mathrm{CHCH}_{2} \mathrm{CH}_{3}}+\mathrm{HCl}
$$

\section{Result}

Formation of 1-chlorobutane $\mathrm{CH}_{3} \mathrm{CH}_{2} \mathrm{CH}_{2} \mathrm{CH}_{2} \mathrm{Cl}$

Table 1. Formation 1-chlorobutane, percentages of correct and incorrect answers.

\begin{tabular}{lccc}
\hline Group & Correct answers & Incorrect answers & No answers \\
\hline EG & $80.6 \%$ & $18.4 \%$ & $1.0 \%$ \\
CG & 61.4 & $35.2 \%$ & $3.4 \%$ \\
\hline
\end{tabular}

There is a statistically significant difference $\left(\chi^{2}=\right.$ 8.727; $\mathrm{df}=2 ; 2 \mathrm{P}=0.013$ ) between the answers of the students who used the concept map as a teaching and learning technique and those who did not use the concept map.

Formation of 2-chlorobutane<smiles>CCC(C)Cl</smiles>

Table 2. Formation 2-chlorobutane, percentages of correct and incorrect answers.

\begin{tabular}{lccc}
\hline Group & Correct answers & Incorrect answers & No answers \\
\hline EG & $43.2 \%$ & $47.7 \%$ & $9.1 \%$ \\
CG & $36.7 \%$ & $62.2 \%$ & $1.0 \%$ \\
\hline
\end{tabular}

2.a $\mathrm{CH}_{3} \mathrm{CH}_{2} \mathrm{CH}_{2} \mathrm{Cl} \rightarrow$<smiles>[3H]C([13CH3])C([13CH3])Cl</smiles>

\section{Solution}

In the elimination of hydrogen chloride from halogenoalkane (ethanolic solution of potassium hydroxide), the appropriate alkene is formed. From the relevant section of the concept map, it is evident that the elimination reaction is of a single stage, and that the product is the same in the case of propane, irrespective of the position of the chlorine atom in the chain.

2.a Reactant 1-chloropropane, formation of propene $\mathrm{CH}_{2}=\mathrm{CHCH}_{3}$

\section{Result \\ $\mathrm{CH}_{3} \mathrm{CH}_{2} \mathrm{CH}_{2} \mathrm{Cl} \rightarrow \mathrm{CH}_{2}=\mathrm{CHCH}_{3}$}

There is no statistically significant difference $\left(\chi^{2}=\right.$ 3.763 ; $\mathrm{df}=2 ; 2 \mathrm{P}=0.15)$ between the answers of the students who used the concept map as a teaching and learning technique and those who did not use the concept map. 
Table 3. Formation of propene (reactant 1-chloropropane), percentages of correct and incorrect answers.

\begin{tabular}{lccc}
\hline Group & Correct answers & Incorrect answers & No answers \\
\hline EG & $64.3 \%$ & $31.6 \%$ & $4.1 \%$ \\
CG & $51.1 \%$ & $45.5 \%$ & $3.4 \%$ \\
\hline
\end{tabular}

2.b Reactant 2-cloropropane, formation of propene $\mathrm{CH}_{2}=\mathrm{CHCH}_{3}$

\section{Result}<smiles>CC=CCC(C)Cl</smiles>

Table 4. Formation of propene (reactant 2-chloropropane), percentages of correct and incorrect answers.

\begin{tabular}{lccc}
\hline Group & Correct answers & Incorrect answers & No answers \\
\hline EG & $66.3 \%$ & $26.5 \%$ & $7.1 \%$ \\
CG & $48.9 \%$ & $45.5 \%$ & $5.7 \%$ \\
\hline
\end{tabular}

There is a statistically significant difference $\left(\chi^{2}=\right.$ $7.268 ; \mathrm{df}=2 ; 2 \mathrm{P}=0.026$ ) between the answers of the students who used the concept map as a teaching and learning technique and those who did not use the concept map.

A number of students, particularly those who did not use the concept map concluded that substitution instead of elimination had taken place and that alcohols were formed (2.a $16.3 \% \mathrm{EG}, 30.7 \% \mathrm{CG}$; $2 . \mathrm{b} 15.3 \% \mathrm{EG}$, $21.6 \% \mathrm{CG})$.

\section{1. 3. Task No. 3}

Are the same products formed in the reaction of 1-chloropropane and 2-chloropropane with an aqueous solution of potassium hydroxide? If not, which products are formed? Complete the reaction schemes.

\section{3.a $\mathrm{CH}_{3} \mathrm{CH}_{2} \mathrm{CH}_{2} \mathrm{Cl} \rightarrow$<smiles>CCC(C)Cl</smiles>

\section{Solution}

In the reaction of a halogenated alkane with an aqueous solution of potassium hydroxide, the substitution of the halogen with a hydroxyl group takes place. In the reaction of 1-chloropropane with an aqueous solution of potassium hydroxide, the primary alcohol propan-1-ol is formed, whereas in the reaction of 2-chloropropane, the secondary alcohol propan-2-ol is formed. In both of these reactions, an aqueous solution of potassium chloride is produced. These changes are reflected in the concept map. 3.a Reaction of 1-chloropropane, formation of propan-1-ol, $\mathrm{CH}_{3} \mathrm{CH}_{2} \mathrm{CH}_{2} \mathrm{OH}$

$$
\mathrm{CH}_{3} \mathrm{CH}_{2} \mathrm{CH}_{2} \mathrm{Cl} \rightarrow \mathrm{CH}_{3} \mathrm{CH}_{2} \mathrm{CH}_{2} \mathrm{OH}+\mathrm{KCl}
$$

Table 5. Formation of propan-1-ol, percentages of correct and incorrect answers.

\begin{tabular}{lccc}
\hline Group & Correct answers & Incorrect answers & No answers \\
\hline EG & $77.6 \%$ & $8.2 \%$ & $14.3 \%$ \\
CG & $73.9 \%$ & $12.5 \%$ & $13.6 \%$ \\
\hline
\end{tabular}

There is no statistically significant difference $\left(\chi^{2}=\right.$ $0.951 ; \mathrm{df}=2 ; 2 \mathrm{P}=0.622$ ) between the answers of the students who used the concept map as a teaching and learning tool and those who did not use the concept map. The most common mistake was the incorrectly noted formula of the resulting alcohol (1\% EG, 6.8\% CG) and the formation of an alkene - propene (1\% EG and $3 \% \mathrm{CG})$.

3.b Reaction of 2-chloropropane, formation of propan-2-ol,

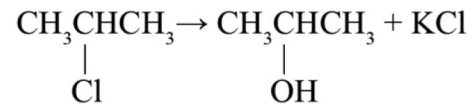

Table 6. Formation of propan-2-ol, percentages of correct and incorrect answers.

\begin{tabular}{lccc}
\hline Group & Correct answers & Incorrect answers & No answers \\
\hline EG & $70.4 \%$ & $14.3 \%$ & $15.3 \%$ \\
CG & $69.3 \%$ & $15.9 \%$ & $14.8 \%$ \\
\hline
\end{tabular}

There is no statistically significant difference $\left(\chi^{2}=\right.$ $0.098 ; \mathrm{df}=2 ; 2 \mathrm{P}=0.952$ ) between the answers of the students who used the concept map as a teaching and learning technique and those who did not use the concept map. The most common mistake was the incorrectly noted formula of the resulting alcohol (5\% EG, $11.3 \%$ $\mathrm{CG})$ and the formation of an alkene - propene (1\% EG and $3 \% \mathrm{CG})$.

\section{1. 4. Task No. 4}

Products formed in the reaction of chlorinated propane with an aquatic solution of $\mathrm{KOH}$ (propan-1-ol, propan-2-ol) oxidate with $\mathrm{K}_{2} \mathrm{Cr}_{2} \mathrm{O}_{7}$ in the acid media. The reaction is carried out with an equivalent quantity of substrates and an oxidant. 
Complete the reaction schemes.

$$
\mathrm{CH}_{3} \mathrm{CH}_{2} \mathrm{CH}_{2} \mathrm{OH} \stackrel{\mathrm{K}_{2} \mathrm{Cr}_{2} \mathrm{O}_{7} / \mathrm{H}^{+}}{\longrightarrow}
$$<smiles>[R4]C(=O)O[14CH2][14CH2][14CH2][14CH](C)O</smiles>

\section{Solution}

$$
\begin{aligned}
& \mathrm{CH}_{3} \mathrm{CH}_{2} \mathrm{CH}_{2} \mathrm{OH} \stackrel{\mathrm{K}_{2} \mathrm{Cr}_{2} \mathrm{O}_{7} / \mathrm{H}^{+}}{\longrightarrow} \mathrm{CH}_{3} \mathrm{CH}_{2} \mathrm{CHO} \\
& \underset{\text { I }}{\mathrm{CH}_{3} \mathrm{CHCH}_{3}} \stackrel{\mathrm{K}_{2} \mathrm{Cr}_{2} \mathrm{O}_{7} / \mathrm{H}^{+}}{\longrightarrow} \mathrm{CH}_{3} \underset{\text { II }}{\mathrm{CCH}} \mathrm{OCH}_{3}
\end{aligned}
$$

Primary alcohols oxidize with an acidic solution of potassium bichromate to aldehydes and further to the carboxylic acids, while secondary alcohols oxidize to ketones under the same conditions. The course of reactions is evident from part of the concept map.

The part of the concept map that addresses the reactions in Task 4.

\section{Result}

4.a Oxidation of the propan-1-ol $\left(\mathrm{CH}_{3} \mathrm{CH}_{2} \mathrm{CH}_{2} \mathrm{OH}\right)$ to propanol $\left(\mathrm{CH}_{3} \mathrm{CH}_{2} \mathrm{CHO}\right)$ is formed.
Table 7. Oxidation of the propan-1-ol, percentages of correct and incorrect answers.

\begin{tabular}{lccc}
\hline Group & Correct answers & Incorrect answers & No answers \\
\hline EG & $65.3 \%$ & $5.1 \%$ & $29.6 \%$ \\
CG & $59.1 \%$ & $17.0 \%$ & $23.9 \%$ \\
\hline
\end{tabular}

There is a statistically significant difference $\left(\chi^{2}=\right.$ $7.004 ; \mathrm{df}=2 ; 2 \mathrm{P}=0.030)$ between the answers of the students who used the concept map as a teaching and learning technique and those who did not use the concept map.

The most frequent mistake in the reaction scheme of propan-1-ol was the formation of butanoic acid (CG $5.7 \%)$

4. b Oxidation of the secondary alcohol propan-2-ol $\left(\mathrm{CH}_{3} \mathrm{CHCH}_{3}\right)$ to propanon $\left(\mathrm{CH}_{3} \mathrm{COCH}_{3}\right)$ is formed.<smiles>O</smiles>

Table 8. Oxidation of the propan-2-ol; percentages of correct and incorrect answers.

\begin{tabular}{lccc}
\hline Group & Correct answers & Incorrect answers & No answers \\
\hline EG & $45.9 \%$ & $5.1 \%$ & $49.0 \%$ \\
CG & $44.3 \%$ & $17.0 \%$ & $38.6 \%$ \\
\hline
\end{tabular}

There is a statistically significant difference $\left(\chi^{2}=\right.$ $7.302 ; \mathrm{df}=2 ; 2 \mathrm{P}=0.026$ ) between the answers of the stu-

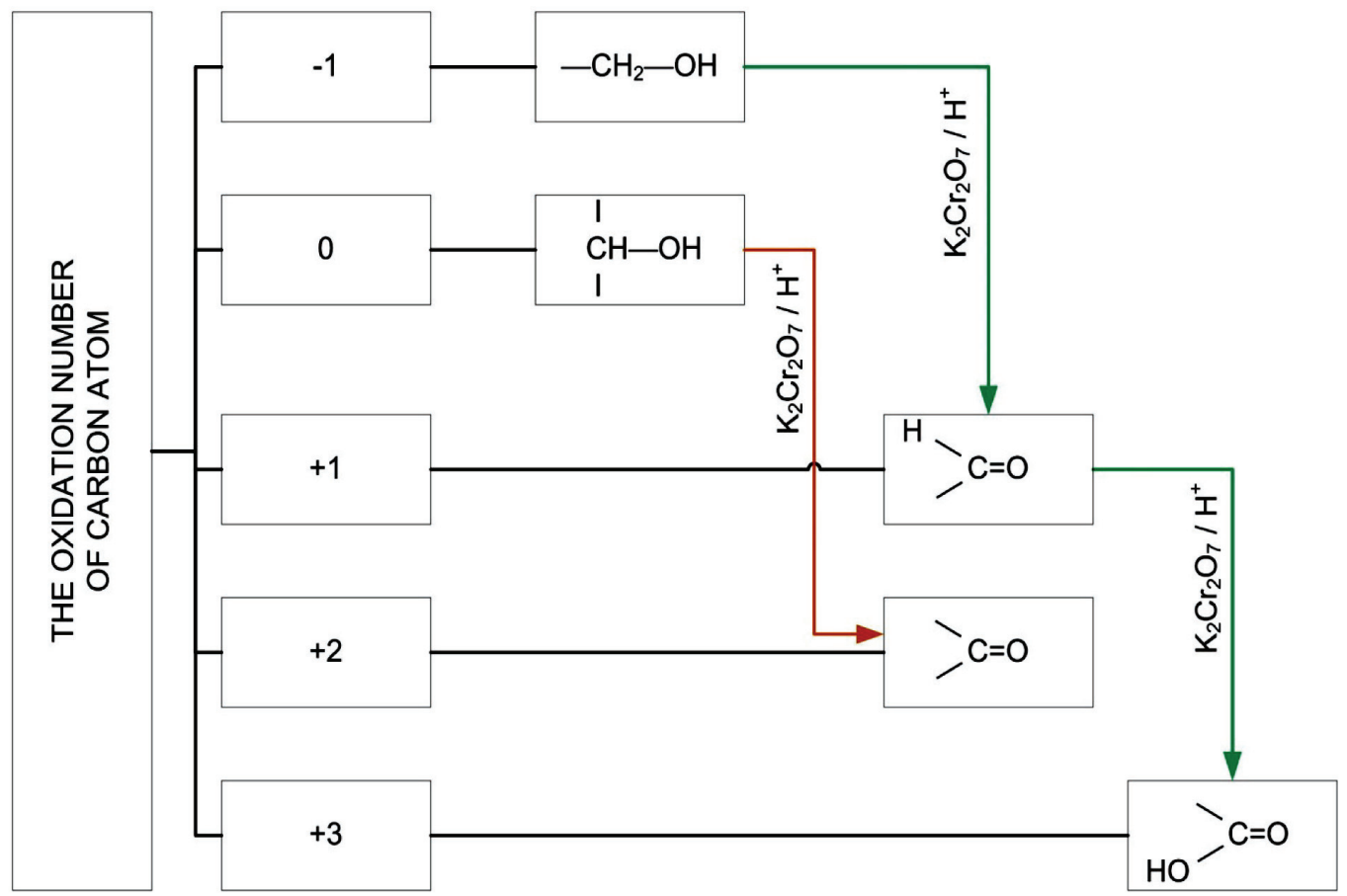

Scheme 3. A part of the concept map is given, dealing with the reactions in Tasks 4 . 
dents who used the concept map as a teaching and learning technique and those who did not use the concept map.

The most frequent mistake in the reaction scheme of propan-2-ol was that the students in the $\mathrm{CG}$ wrote down the formula of butan-2-ol $\mathrm{CH}_{3}-\mathrm{CH}_{2}-\mathrm{CH}(\mathrm{OH})-\mathrm{CH}_{3}$ as a reactant, and the formation of the products $\mathrm{CH}_{3}-\mathrm{CH}_{2}-\mathrm{CO}$ $\mathrm{CH}_{3}(\mathrm{CG} 5.7 \%), \mathrm{CH}_{3}-\mathrm{C}(\mathrm{KCl})-\mathrm{CH}_{3}-\mathrm{OH}$ and $\mathrm{CH}_{3}-\mathrm{C}(\mathrm{KCl})-$ $\mathrm{COOH}(3.4 \% \mathrm{CG})$, while the students in the EG incorrectly wrote down the formula of the resulting product $\mathrm{CH}_{3}-\mathrm{CH}-\mathrm{CH}_{3}(4.1 \%)$.

\section{Discussion and Implications for Teaching}

The object of the study was to evaluate the impact of using a concept map on solving tasks in the field of organic reactions. In so doing, the focus was on determining the number and types of errors in solving tasks with and without the use of a concept map as a teaching and learning technique. In teaching, a concept map was used that includes reactions for three types of organic molecules: hydrocarbons, organic halides and organic oxygen-containing compounds. The basis for the construction of the concept map is the oxidation number of the carbon atom, which is determined with regard to the electronic affinity of the carbon atom as compared to the hydrogen atom or a hetero atom.
The study involved a sample of 186 students, who were divided into an experimental group (98 students), which applied the concept map as a teaching and learning technique, and a control group (88 students), which did not use the concept map. There was no statistically significant difference between the two groups in the results of the TOLT test and in the students' final grades in chemistry. A knowledge test, consisting of four tasks with multiple parts, was applied as a quantitative tool for the evaluation of the impact of the concept map on problem solving.

In the knowledge test achievements, there is a statistically significant difference at the level of significance $\mathrm{p}=0.03$ between the experimental group $(\mathrm{M}=15.9 ; \mathrm{SD}=$ 6.33) and the control group $(\mathrm{M}=13.6$; $\mathrm{SD}=7.93)$; $\mathrm{t}(166.35)=-2.16$. Pearson's correlation coefficient shows that there is a moderately strong statistically significant correlation $(r=0.321, p \leq 0.000)$ between the grades in chemistry and the knowledge test achievements. It can be concluded that the use of the concept map as a teaching and learning technique by the experimental group students resulted in better knowledge test performance. The $\mathrm{t}$-test for independent samples shows that the differences in knowledge test performance between the sexes are not statistically significant $(\mathrm{t}(184)=0.457, \mathrm{p}=0.648)$.

The students in the experimental group, who used the concept map, performed significantly better in the tasks dealing with the chlorination of butane (Tasks 1.a. and 1.b.), the elimination of hydrogen chloride from 2-chlorobutane (Task 2.b), and the oxidation of primary

Table 9. Overview of the solving of individual tasks by the experimental and control group students.

\begin{tabular}{|c|c|c|c|}
\hline Task & $\begin{array}{c}\text { EG } \\
\% \text { Correct answers }\end{array}$ & $\begin{array}{c}\text { CG } \\
\% \text { Correct answers }\end{array}$ & $\begin{array}{c}\text { Statistically significant } \\
\text { difference }\end{array}$ \\
\hline $\begin{array}{l}\text { 1. a chlorination of butane } \\
\mathrm{CH}_{3} \mathrm{CH}_{2} \mathrm{CH}_{2} \mathrm{CH}_{2} \mathrm{Cl}\end{array}$ & $80.6 \%$ & $61.4 \%$ & Yes \\
\hline $\begin{array}{l}\text { 1. b chlorination of butane } \\
\mathrm{CH}_{3} \mathrm{CH}_{2} \mathrm{CHCH}_{3} \\
\mathrm{Cl}\end{array}$ & $36.7 \%$ & $43.2 \%$ & Yes \\
\hline $\begin{array}{l}\text { 2. a elimination of hydrogen chloride } \\
\mathrm{CH}_{3} \mathrm{CH}_{2} \mathrm{CH}_{2} \mathrm{Cl} \rightarrow \mathrm{CH}_{2}=\mathrm{CHCH}_{3}\end{array}$ & $64.3 \%$ & $51.1 \%$ & No \\
\hline $\begin{array}{l}\text { 2. b elimination of hydrogen chloride } \\
\mathrm{CH}_{3} \mathrm{CHCH}_{3} \rightarrow \mathrm{CH}_{2}=\mathrm{CHCH}_{3} \\
\mathrm{Cl}\end{array}$ & $66.3 \%$ & $48.9 \%$ & Yes \\
\hline $\begin{array}{l}\text { 3. a substitution of halogen by the hydroxyl group } \\
\mathrm{CH}_{3} \mathrm{CH}_{2} \mathrm{CH}_{2} \mathrm{Cl} \rightarrow \mathrm{CH}_{3} \mathrm{CH}_{2} \mathrm{CH}_{2} \mathrm{OH}\end{array}$ & $77.6 \%$ & $73.9 \%$ & No \\
\hline $\begin{array}{l}\text { 3. b substitution of halogen by the hydroxyl group } \\
\mathrm{CH}_{3} \mathrm{CHCH}_{3} \rightarrow \mathrm{CH}_{3} \mathrm{CHCH}_{3} \\
\mathrm{Cl}\end{array}$ & $70.4 \%$ & $69.3 \%$ & No \\
\hline $\begin{array}{l}\text { 4. a oxidation of the primary alcohol } \\
\mathrm{CH}_{3} \mathrm{CH}_{2} \mathrm{CH}_{2} \mathrm{OH} \rightarrow \mathrm{CH}_{3} \mathrm{CH}_{2} \mathrm{CHO}\end{array}$ & $65.3 \%$ & $59.1 \%$ & Yes \\
\hline $\begin{array}{l}\text { 4. b oxidation of the secondary alcohol } \\
\mathrm{CH}_{3} \mathrm{CHCH}_{3} \rightarrow \mathrm{CH}_{3} \mathrm{CCH}_{3} \\
\mathrm{OH}_{\mathrm{OH}}\end{array}$ & $45.9 \%$ & $44.3 \%$ & Yes \\
\hline
\end{tabular}


and secondary alcohol (Tasks 4.a and 4.b). Furthermore, the tasks addressing the elimination of hydrogen chloride from 1-chloropropane (Task 2a) and the substitution of halogen by a hydroxyl group in 1-chloropropane and 2-chloropropane (Tasks 3.a and 3.b) were better solved by the students in the experimental group, although the difference relative to the students in the control group is not statistically significant in this case.

The students of both groups (the experimental and the control group) made similar errors in solving individual tasks, but the percent of students who used the concept map making the mistake was smaller.

\section{Overview of errors:}

(1) Recording only one mono-substituted product in the reaction of substitution, although in the molecule of butane there are two different types of $\mathrm{C}-\mathrm{H}$ bonds, and in the reaction with chlorine two mono-substituted products are formed.

(2) Failure to take into account the conditions in the course of organic reactions, e.g., the conditions under which the elimination takes place, and the conditions under which substitution takes place in the reactions of halogenoalkanes.

(3) Failure to take into account the fact that the carbon atom can form four bonds in the molecules of organic compounds.

(4) Failure to take into account Markovnikov's Rule with the addition of water to alkanes.

(5) Differentiation of the oxidation products of primary and secondary alcohols; formation of the corresponding aldehyde or acid from primary alcohols and ketones from secondary alcohols.

Based on the results of the research, it can be established that the use of a concept map, which was applied as a teaching and learning technique in the case of the students in the experimental group, had an impact on improving the achievements of this group in solving the problem tasks.

Concept mapping is an instructional strategy for learning that involves the integration of knowledge of concepts and relations among them. ${ }^{24}$ An expert map provides for a standard against which students are measured, but gives the researcher no information about the students' individual understanding. A future study might consider a module in which students would do both - use the expert map and generate their own maps. The students' concept maps could be assessed against the expert map. The differences between the students' maps and expert maps can support teaching to avoid misconceptions and can contribute to developing knowledge with understanding.

\section{References}

1. M. Vrtačnik, N. Gros, Acta Chim. Slov. 2013, 60, 209-220.

2. B. Kralj, S. A. Glažar, Acta Chim. Slov. 2013, 60, 433-441.
3. K. S. Wissiak, V. Ferk Savec, Acta Chim. Slov. 2014, 61, 729-739.

4. B. Šket, S. A. Glažar. Acta Chim. Slov. 2005, 4, 471-477.

5. D. P. Ausubel, Educ. Psychol. 1977, 2, 162-178. http://dx.doi.org/10.1080/00461527709529171

6. N. M. Seel, Encyclopedia of the Sciences of Learning. Dordrecht Heidelberg: Springer 2012, 324-326. http://dx.doi.org/10.1007/978-1-4419-1428-6

7. J. D. Novak, D. B. Gowin, Learning How to Learn. Cambridge: Cambridge University Press 1984, 15-40. http://dx.doi.org/10.1017/CBO9781139173469.004

8. L. Cardellini, J. Chem. Educ. 2004, 81, 1303-1308. http://dx.doi.org/10.1021/ed081p1303

9. D. P. Ausubel, J. Educ. Psychol. 1960, 5, 267-272. http://dx.doi.org/10.1037/h0046669

10. C. Harris, S. Zha, Educ. 2013, 134, 5-19.

11. A. M. Collins, M. R. Quillian, J. Verb. Lear. Verb. Behav. 1969, 1, 240-247. http://dx.doi.org/10.1016/S0022-5371(69)80069-1

12. J. D. Novak, A. J. Cañas, The Theory Underlying Concept Maps and How to Construct Them, Technical Report IHMC CmapTools 2006-01 2008, Pensacola FL: Institute for Human and Machine Cognition, 31 p. http://cmap.ihmc.us/ Publications/ResearchPapers/TheoryUnderlyingConceptMa ps.pdf.

13. D. H. Jonassen, Instructional design theories and models. In C. M. Reigeluth (Ed.), A new paradigm of instructional theory, Volume II. Mahwah, NJ: Lawrence Erlbaum Associates 1999, 215-240.

14. K. M. Edmandson, Assessing science understanding through concept maps. In J. J. Mintzes (Ed.), J. H. Wandersee (Ed.), J. D. Novak (Ed.), Assessing science understanding: A human constructivist view. San Diego: Academic Press 2000, 19-36.

15. Y. Yin, J. Vanides, M. M. Ruiz-Primo, C. C. Ayala, R. J. Shavelson, J. Res. Sci. Teach. 2005, 42, 166-184. http://dx.doi.org/10.1002/tea.20049

16. M. Pill, Enhancing Teaching in Higher Education. Abingdon, UK: Routledge 2005.

17. A. O. Qarareh, Stud. Home Comm. Sci. 2010, 4, 155-160.

18. J. W. Cilburn, J. Coll. Sci. Teach. 1990, 4, 212-217.

19. J. E. Trowbridge, J. H. Wandersee, Theory Driven Graphic Organizers. In J. J. Mintzes (Ed.), J. H. Wandersee (Ed.), J. D. Novak (Ed.) Teaching Science for Understanding a Human Constructivist View, Vol. 3, New York: Elsevier Academic Press 1998, 3-27.

20. J. Gulmans, Mapping for the Constructivistic Acquisition of Concepts? In: P. A. Kommers (Ed.), Cognitive support for learning: Imagining the Unknown. Amsterdam: Ios Press 2004, 31-45.

21. P.-H. Wu, G.-J. Hwang, M. Marcelo, H.-R. Ke, Brit. J. Educ. Technol. 2012, 43, 217-232.

http://dx.doi.org/10.1111/j.1467-8535.2010.01167.x

22. K.-H. Tseng, C.-C. Chang, S.-J. Lou, C.-J. Chiu, Educ. Technol. Soc. 2012, 15, 102-115.

23. B. J. Daley, D. M. Torre, Med. Educ. 2010, 44, 440-448. 
http://dx.doi.org/10.1111/j.1365-2923.2010.03628.x

24. D. M.Torre, S. J. Durning, B. J. Daley, Med. Teach. 2013, 35, 201-208. http://dx.doi.org/10.3109/0142159X.2013.759644

25. J. Simon, J. Acc. Educ. 2010, 19, 301-307. http://dx.doi.org/10.1080/09639280903411336

26. J. Vanides, Y. Yin, M. Tomita, M. A. Ruiz-Primo, Sci. Scope 2005, 8, 27-31.

27. S. BouJaoude, M. Attieh, EJMSTE 2008, 4, 233-246.

28. B. A. Qais, Sci. Educ. 2004, 25, 123-145.

29. A. Candan, J. Turk. Sci. Educ. 2006, 3, 66-75.

30. E. Erdem, A. Yılmaz, Ö. Ö. Oskay, Procedia Soc. Behav. Sci. 2009, I, 1586-1590.

http://dx.doi.org/10.1016/j.sbspro.2009.01.279
31. G. Nicoll, J. S. Francisco, M. Nakhleh, Int. J. Chem. Educ. 2001, 23, 863-875.

32. J. Gurlitt, A. Renkl, J. Comput. Assist. Learn. 2008, 24, 407-419. http://dx.doi.org/10.1111/j.1365-2729.2008.00277.x

33. K. Tobin, W. Capie, Educ. Psychol. Meas. 1981, 41, 413- 423. http://dx.doi.org/10.1177/001316448104100220

34. F. J. Gravetter, L.-A. B. Forzano, Research Methods for the Behavioral Science. Belmont: Wadsworth, Cengage Learning 2009.

\section{Povzetek}

Namen raziskave je bil ugotoviti vpliv vključevanja pojmovne mape v pouk in s tem na reševanje nalog s področja organskih kemijskih reakcij. V prvi stopnji raziskave je bila izdelana pojmovna mapa za reakcije ogljikovodikov, organskih halogeniranih in kisikovih spojin. V drugi stopnji je bila izdelana pojmovna mapa uporabljena pri pouku. Njen vpliv na razumevanje organskih kemijskih reakcij je bil preizkušen na vzorcu 186 dijakov (povprečna starost 17,8 let). Dijaki so bili razdeljeni v kontrolno (88 dijakov) in eksperimentalno skupino (98 dijakov). Dijaki obeh skupin so bili izenačeni v stopnji formalno logičnega mišljenja in srednje ocene iz kemije. Kot kvantitativen inštrument za merjenje vpliva uporabe pojmovne mape je bil uporabljen preizkus znanja, sestavljen iz štirih problemov, ki so vključevali več podproblemov. Vsebina preizkusa znanja je pokrivala organske kisikove spojine glede na gimnazijski učni načrt. Analiza rezultatov reševanja preizkusa znanja kaže med kontrolno in eksperimentalno skupino statistično pomembno razliko (kontrolna skupina $\mathrm{M}=13,6 ; \mathrm{SD}=7,93$, eksperimentalna skupina $\mathrm{M}=15,9 ; \mathrm{SD}=6,33 ; \mathrm{p}=0,03$ ). Izdelana pojmovna mapa je vplivala na učinkovitejše povezovanje pojmov, kar je vplivalo na uspešnejše reševanje problemov. 